\author{
Cristop h er G. Pickvance
}

\title{
ON THE STUDY OF URBAN SOCIAL MOVEMENTS
}

\section{Introduction}

The aim of this article is to initiate a discussion of the recent series of studies of 'urban social movements'. These studies share a common conceptual framework which is derived from a 'structuralist' rcading of Marx and is set out in a preliminary form by M. Castells in La Question Urbaine. This framework matks a break with the anglo-saxon tradition of 'participation' studies which are charactcrized by a focus on the individual and his membership of, or participation in, a smaller or greater varicty of 'voluntary associations' and other groupings. ${ }^{1}$ Within this tradition largescale survey studies are carried out to cstablish the degree of 'participation', as opposed to the extent of 'anomie' of the population. The social implications of organizational membership ate inferred, not studied explicitly. Thus membership may be secn as entailing participation in decisionmaking, in so far as the organization has an informal or formal position in the local social structure, or on the other hand, as facilitating the acquisition of skills and democratic values which encourage political activity in other contexts. What has been lacking within the 'participation' tradition is any intensive study of voluntary associations and other groupings to establish empirically (rather than by inference) what functions membership has.

Conversely, studies within the 'urban social movements' approach,

1. See Pickvance (1974) for a discussion of this tradition. 
firstly, de-emphasize the form of the organization in which 'participation' takes place ${ }^{2}$ and view organization primarily as a means by which contradictions are linked, and, secondly, stress the effects or otherwise of the movement. These points will be discussed briefly, in turn.

Organizations, according to Castells (1972:341) are precisely the wrong starting-point for studies of urban social movements. This does not mean that concrete organizations, or, as Ash (1972:2) would call them, 'movement organizations', can be ignored. On the contrary, as the studies to be discussed will indicate, concrete movement otganizations are the locus of observation. The point is that they are not the frame of analysis. The focus of analysis is rather on the 'problems', 'issues' or 'stakes' the organization pursues and their structural determination. It is the structural contradictions which are the crucial level of analysis, and organizations are seen as means for their expression and articulation. Thus the point is that organizations cannot be analysed without reference to these functions, not that organizations are unimportant. In this respect, the "urban social movements' approach is opposed to the 'participation' approach for which the analysis of otganizations and their resources is an important focus of analysis, which we will return to in section 4 .

The emphasis on 'effects' is part of the definition of urban social movements, which must now be briefly examined since it is the source of some ambiguity. An urban social movement is defined as:

«a system of practices resulting from the articulation of a conjuncture of the system of urban agents with other social practices, such that its development tends objectively towards the structural transformation of the urban system, or towards a substantial change in the balance of power in the class struggle, that is to say, in the power of the State.» (Castells, 1972:329.)

The important point about this definition is that it defines urban social movements by a specific type of effect. It follows that when these effects are not obtained ( 0 , to be precise, when the 'objective development' of the organization would not lead to such effects), then the description 'urban social movement' is not appliable. For this reason Castells identifies two lower levels of effect, namely, 'reform', i.e., change in an element of

2. This is evident from a perusal of any of the studies to be discussed, «The genesis of organization is not the concern of an analysis of social movements, for only their effects are of importance.) (Castells, 1972:339. N. B. All translations ate my own.) In section $4 \mathrm{I}$ shall argue that the resources available to an organization affect both its survival and success. 
the urban system without any change in its internal relations, and 'control', i.e. the reproduction of the urban system. When these levels of effect result, the correspondign types of organization are described as 'protest' and 'participation', respectively. Thus, according to the effects achieved an organization can be placed on the scale: 'participation', 'protest', 'urban social movement'. Castells argues that an organization where the contradictions involved are purely 'urban', (i.e., concerned with the spatial unit of the reproduction of the labour force (see Castells, 1972:295-304) e.g. issues such as housing, education, and collective facilities), and not linked to tre 'political' or 'economic' aspects of class struggle, can at most be un 'instrument of reform' (1972:340). It is only when an urban social movement unites economic or political contradictions with urban contradictions, that the term in its strict sense can be said to apply.

In the studies to be discussed urban social movements are generally not linked to trade unions or political parties. However we shall follow the practice they adopt and use the term urban social movement irrespective of the level of effects.

There is also an ambiguity in the use of the term 'effect'. We shall follow Olives (1972) and refer to urban effects as those urban objectives which have been successfully achieved, rather than Lentin (1973) who includes both failures and successes. (A similar difference can be seen in the treatment of 'political effects'.)

We can now proceed to analyse a number of features of recent 'structuralist' studies of urban social movements in France. Our discussion will be in four parts:

(1) The identification of urban effects.

(2) Local authorities and urban effects.

(3) Institutional action and urban effects.

(4) Organizational resources and urban effects.

My aim is not to question the usefulness of the structuralist Marxist approach nor to attempt a full-scale critique of the studies so far carried out, but simply to indicate several fields which deserve further cultivation.

\section{(1) The identification of urban effects}

To talk about the effects of a movement organization (or 'system of practiccs') is to imply that an antecedent event causes a subsequent event, e.g., that a petition against eviction causes a decision to rehouse the tenants concerned, by an authority.

In ordcr to make a causal inference of this sort it is necessary but not 
sufficient that the two events occur in a given temporal order. To establish the existence of a causal relation we need additional evidence. Scrictly speaking, if we follow Blalock's analysis of causality, it is never possible to observe causality, since it is a notion belonging to a theorctical rather than an obscrvational language. (Blalock, 1964: chaps, 1 and 2.) In other words we can never have entirely satisfactory evidence of causality. But causal inference requires two types of evidence: evidence about temporal order, and evidence about the perceptions of the relevant actors. (These correspond to Weber's requirements of causal adequacy and adequacy at the level of meaning for sociological understanding. Sce Weber, 1947: 98-100).

The argument I wish to advance is that the structuralist studies of urban social movements frequently fail to offer both types of evidence. In particular they emphasize the action of the movenent organization at the expense of the action of the 'authority'.

There would appear to be two teasons for this bias. The first is practical; the second is theoretical.

The practical reason derives from the differing accessibility of movemont organizations and 'authorities' to the research-worker. Movement organizations are more easily penetrated by the rescarch-worker and it is natural that the information gathered on them will be correspondingly richer. This greater accessibility facilitates the understanding of the subjective meaning of action to the actors, and enables it to be correctly characterized as a particular type of 'action' rather than as 'behaviour', to follow Weber's distinction. (Weber, 1947:88-90.) Participant observation in movement organizations also enables action to be observed as it takes place and thereby avoids reliance on accounts by participants given after the event in response to interviewing.

The accessibility of movement organizations carries with it a risk for the research-worker. Namely, that he comes to identify with the organization and its aims, and thus loses his ability to present a more complete analysis. In particular, I suggest, there is a danger that the research-worker tends to attribute too much causal influence to the actions of the movement organization and insufficient influence to the actions of the autbority. His inferences about cause and effect thus become 'movement-centred' because of bis involvement in the movement organization.

For example, Lentin describes the attempts by local residents to prevent the construction of a new building in an old quarter of Paris, and the 'institutional approaches' they made, (c.g., a written question to the Prefet of Paris, sent via municipal councillors, an interview with the depputé maire.) She then continues: 
'The tetort was not long in coming: a new building permit was issued, this time accompanied by an agreement from the Ministry of Cultural Afairs.' (1973:97)

The fact that the word retort is used indicates the way in which (negative) causal influence is attributed to the movement organization. The fact that the permit was issued after the 'institutional approaches' may, rather, have been a coincidence. For example, the pressure by the developers, which Lentin alludes to, may have been continuing for some time.

This leads us to a second and theoretical reason which could account for the emphasis placed on the actions of the movement organization at the expense of the actions of the authority. Namely, the theoretical assumptions made about 'authorities' within the structural Marxist approach. As will be indicated in more detail in the next section, it is taken as axiomatic within this approach that authorities will not grant changes which threaten the stability of the mode of production. But, as we saw earlier, purcly urban social movements are not considered to be capable of provoking changes of this scale and the empirical studies bear this out. It appears to me that a different theorctical assumption is also being made, namely, that 'authorities' will not grant concessions of any scale without the intervention of social movements. This assumption, if indeed it is being made, is highly debatable, and, in any case, does not follow from the axiom just mentioned. Thus, I suggest, acceptance of the assumption that 'authorities' will grant no concessions at all unless forced to by social movements is a second possible explanation of the movement-centred inferences about cause and effect.

In order to identify the causes of urban effects more accurately it would seem necessary:

- to be aware of the risks of ovcr-involvement in movement organizations, and

- to examine the assumptions being made about the role of authorities as causes of change. This rcquires empirical study of the authorities. It is to this subjec that we now turn.

\section{(2) Local autborities and urban effects}

The relative toles of the State and urban social movements in producing urban effects are spelled out by Castells as follows:

«If it is true that the State expresses, in the last instance and 
through the necessary mediations, the overall interests of the dominant classes, urban planning cannot be an instrument of social change, but of domination, integration and regulation of contradictions.

»A process of social change starting from this new field of urban contradictions occurs when, on the basis of these themes, popular mobilization takes place, social interests are translated into political will and other forms of organization of collective consumption, in contradiction with the dominant social logic, are put into place. Thus it is urban social movements and not planning institutions wbich are the true sources of change and innovation in the city.» (1973: 18,19 )

These two quotations identify urban planning, on the one hand, and urban social movements, on the other, with the functions of control and innovation, respectively. They derive from a specifically Marxist view of the State, and it is this view which requires examination. The two quotations contain a slight ambiguity, namely, as to whether the 'social change' which authorities seek to control refers only to major changes, or whether it also refers to minor changes. We shall assume the latter interpretation is correct, and therefore that even small changes can only be brought about by social movements. This certainly seems to be the assump. tion of the empirical studics of urban social movements.

In this section our aim is to argue that governmental institutions cannot be dismissed as sources of minor changes, and to this extent must be treated as sources of urban effects in the same way as social movements. In other words that the role of authorities in initiating changes is an empirical question requiring analysis of policy-formation within governmental institutions.

In the previous section we argued that the inaccessibility of authorities to the research-worker was one practical reason for their neglect as sources of urban effects. It is only by studying processes of policy-formation within authorities (i.e. establishing their degree of autonomy) that one can correctly estimate the relative importance of social movements, on the one hand, and factors internal to the State, on the other.

One study which does attempt to consider policy-making is that by Dearlove (1973) which concerns the London borough of Kensington and Chelsea. He shows that pressure groups are evaluated by the local authority in terms of three factors: their imagen ('helpful' or 'unhelpful'), the demands they advance (conforming or conflicting with existing policy and resource allocation) and their style of action (communication via local councillors, petitions, usc of local press, demonstrations, etc.) (Dearlove, 1973: 
chap. 8) He suggests that the most successful pressure groups are those which are perceived as 'helpful', those whose demands conform to council policy, and those who adopt 'acceptable' modes of action. Unfortunately his conclusions are based on interviews with councillors on policy-making in general rather than on a detailed analysis of the formation of specific policies which would enable his argument about the relative success of diffcrent prcssure groups to be tested. Thus he does not succeed in demonstrating the authority's autonomy in dealing with pressure groups. However the councillor's perceptions he repports are consistent with the existence of such autonomy. (It may also be noted that mass support was not a criterion by which pressure groups were evaluated.)

A second study concerning an urban social movement whose success is explicitly related by the author to pressures internal to the local authority is that by Ferris (1972) carried out in the London borough of Islington. The study shows, inter alia, how the Barnsbury Association, an organization of ncwly-arrived middle-class owner-occupiers concerned over the threat to the amenity value of the area posed by council redevclopment plans, proposes and is successful in getting approved a 'traffic management scheme' by which traffic is routed around the area. (The majority of the population, long-established tenants, opposed the traffic scheme which they saw as irrelevant to their needs, and through another organization, the Barnsbury Action Group, sought to improve their own housing conditions, if necessary through council redevelopment.) The traffic scheme was not accepted without considerable effort by the Association. This included getting Association members clected as local councillors and putting pressure on the local authority in this way. However the important point for present purposes is that the Barnsbury Association's traffic proposals fitted in with central government policy which was 'to change local authority attitudes towards large redevelopment projects' since the latter were very costly in terms of public funds, and to encourage 'ways of upgrading existing environments... [by applying] Buchanan's ideas on traffic, and improving older housing where possible.' (Fertis, 1972:66.) It seems unlikely that the Association would have been successful without the favourable 'policy environment' of central government. Thus the 'urban effect' obtained was the result of the movement organization and factors internal to the autbority. ${ }^{3}$

Ferris's study is unusual in that it does examine factors other than

3. Admittedly the «effect» posed no threat to the urban system: it was favoured by property developers since it raised property values, but opposed by the local authority for financial reasons. 
social movements in producing urban effects. Dearlove, as we have seen, suggests that councillor's perceptions of pressure groups are relcvant to council policy. Cherki has argued that 'wherever the risks of mobilization, of further squatting, of political development, are limited... squatting is tolerated' (1973:85). Presumably this correlation can be traced back to the local autbority's perception of the (limited) challenge to itself, in such cases.

The importance of pressure other than that by social movements is hinted at in two other studies. Pingeot and Robert, in their study of a movement against a proposal to expand an airport, write that the major part of the struggle in the second (and decisive) phase "no longer took place in public (in the street and in the press) but in the corridors of Prefectorates and Ministries' (1973:137), where 'the pressure brought to bear is a direct reflection of the place of each of the protagonists in the social structure' (1973:141). Similarly, Lentin, argues that the decision to issue a building permit 'invites us to suppose the supremacy of one ministry over another, teflecting the strength of the pressure group constituted by the property developers over the bearers of urban ideology, represented by the Ministry of Cultural Affairs'. (1973:97.)

Thus in all these cases it is accepted that urban social movements are not the exclusive sources of (small) changes, and that their demands are perceived by the authorities and balanced against their own policy preferences and against the pressures of other urban actors. It is only when aulborities themselves are made the subject of study, admittedly a difficult requirement to meet, that it will be possible to attribute 'urban effects' to the actions of urban social movements, autbority policy, and otber urban actors (e.g. property developers, otber levels of autbority, etc. ${ }^{4}$ )

\section{(3) Institutional action and urban effects}

A reading of the structuralist studies of urban social movements in France makes clear the emphasis on the role of 'popular mobilization' and 'non-institutional' means in achieving urban effects. By contrast, 'institutional' action in dc-cmphasized. Thus, for example, Lentin writes that the issuing of a building permit despite the approaches of local residents 'shows the limits of institutional action' (1973:97). But, as mentioned before,

4. 'I'he distinction between urban social movements, athority policy and other utban actors is unsatisfactory, since, for cxamplc, authority policy itself will be partly a response to pressure from previous social movements (e.g. for public housing) and other urban actors. 
Lentin herself refers to the pressure of the property developers, which would appear to be an alternative explanation of the residents' 'failure'. In other words, her characterization of the 'failure' indicates a certain attitude to 'institutional action'.

It is worth noting here that the term 'institutional action' is somewhat ambiguous, since the concept 'institution' is itself open to various interpretations. It will be assumed here that 'institutional action' is action which takes place within cxisting political institutions (e.g. voting, petitions to local councillors, deputations, legal demonstrations, or the formation of legal political parties) or within the framework of the law. 'Non-institutional' action thus includes illegal action (violent demonstrations, 'direct action') and the formation of illegal political parties. Mobilization cannot itself be said to be institutional or otherwise; this depends on the forms which it takes.

The question we need to ask is whether 'popular mobilization' is in fact the only successful mode of political action. The study by Olives (1972) is particularly helpful in answering this question. Olives discusses 16 urban social movements in the 'Cite d'Aliarte' in Paris. In nine cases (Nos. 1, 3-10 the objectives sought are at least partly attained. ${ }^{5}$ In the remaining scven cases (Nos. 2, 11-16) failutes result.

In all but two of the nine cascs, the clements organization, mobilization, social base and 'strong' stakes were present. In other words these seven cases correspond to the idea of political action through mobilization. It will be instructive to examine the two exceptions to this rule. They are cases 7 and 8 .

In case 8 an immigrant welfare association used petitions to secure adequate rehousing for immigrants threatened with eviction. This apparent success does not fit in with the idea of change through mobilization. It corresponds to the political effect described as 'social integration (paternalism)' by Castells (Olives, 1972:16). In case 7 the same welfare association again succeeded in obtaining 'adequate rehousing' for immigrants threatened with eviction; a 'local political organization' was also involved. (The corresponding political effect here is described as 'political disintegration (institutional political integration)').

Olives's comments on cases 7 and 8 are interesting:

'In [these] cases - even if the success in obtaining [adequate]

5. These figures are based on the tables in the article (pp. 18-27). On p. 13 Olives refers to the «scven actions which had an urban effect». He appears to have excluded cases 7 and 8 from the nine cases so described in the tables. 
rehousing may lead one to believe in a greater success of the action, we are inclined to believe the contrary to be true, in that either no mobilization of social force took place (No. 8) or else it was too weak (No. 7) to impose as a precondition of 'adequate' rchousing, that residents should rcmain in their homes.' (Olives, 1972:15-16.)

For this reason, Olives considers that the only 'solid urban effect' is the right of residents to remain in their homes after attempts at cviction 'in so far as it is the very evidence of an imposition by force, and thus of a victory capable of being capitalized on by political struggle' (Olives, 1972:16). In other words he makes a distinction between 'solid' urban effects obtained by force, and those obtained by the immigrant welfare association (viz. adequate rehousing) without mobilization. A distinction is made among the ends because of the differing means used. This is regrettable since it obscures the fact that urban effects may be obtained by institutional as well as by non-institutional means. Of coutse, there may be political reasons for making such a distinction, namely, to deny the effectiveness of a type of action (institutional action) which does not correspond to the type eregarded as basic, but this seems beside the point. (Certainly, the fact that mobilization was not involved in obtaining adequate rehousing in cases 7 and 8 alfects the potential of this 'effect' for future political action. But at the lcvel of the urban system there seems no justification for a distinction between types of urban effect according to the means used.)

Thus Olives's study demonstrates that urban effects may result (to an unknown extent) from both institutional and non-institutional modes of action. Admittedly, the types of affect concerned can, at most, be described as 'reform'. A different conclusion might be reached if the stakes were mote important.

Bonnier (1972), in a study of neighbourhood associations, also indicates the success of institutional means, as opposed to popular mobilization. He writes that:

"It can be seen that most of the neighbourhood associations' successes were in fact obtained by winning the attention of municipal leaders, less by any real mobilization of local residents than by secret dcalings or personal approaches by neighbourhood leaders to municipal figures.» (1972:32.)

Bonnier describes these two models as 'new' (mobilization) and 'old' 
(personal relations). The justification for these descriptions is not entirely clear, but the important point is that they are analytically distinct modes of action for an urban social movement. ${ }^{6}$

Finally, we will refer briefly to three urban social movements in Britain in which institutional means played an important part.

Dennis (1972) describes the efforts by residents in an area designated for clearance in Sunderland, to 'participate' in planning the future of the area. A residents' association was constituted, Dennis being the secretary. The association decided to communicate with the Panning Committee (of elected representatives) rather than with the Planning Department (1972: chaps. 13-16). This decision resulted in one-way communication, since the Planning Department refused to answer letters unless its competence was recognized. This the association refused to do: hence, 'participation' terminated. This was not the end of the story for the association then turned to local councillors and the press $(1972: 213)$ and, according to Dennis, the result was withdrawal of the plans to clear the area, and the provision of grants for house improvement, mortgages for house purchase, i.c., the 'revitalization' of the area. Unfortunately Dennis falls into the error identified in section 1 of underestimating factors other than the actions of the association in producing this urban cffect. For example the growing central government disenchantment with large-scale tedevelopment, mentioned by Ferris may have been a factor. The point about Dennis's study is that in addition to the mobilization of public opinion in general (and not merely that of local residents) which may or may not be described as institutional, he attributes success to the intervention of local councillors, who clearly represent an institutional means of action.

A second study, by Davies (1972), in Newcastle, may also be mentioned. Like Dennis, Davies acted as secretary of a residents association in an area threatened by redevelopment. He writes that the association's demands, e.g., for the work to be phased over five years so that existing residents could benefit, and for council 'direct labour' to carry out the clearance/tedevelopment operation, were only met when control of the local council changed from Labour to Conservative. (Davies, 1972:170-1.) Again it is possible that the change in central government thinking on redevelopment played its part.

This study reinforces our argument in section 2 that local authority

6. The term «institutional» is inappropriate to describe the personal relations model of political change since it is not institutionally provided for. Although it would result in confusion to introduce it here, Mitchell's distinction between «structural» and "personal» levels of analysis is relevant. (1969:9-10.) 
policy must be regarded as a factor capable of producing change, al least in conjunction with urban social movements.

$A$ third study in which institutional means were effective is that by Ferris of the Barnsbury Association, mentioned in section 2. The interesting point for present purposes, is that the local authority was very much aware that the Barnsbury Association represented only a minority (albeit a highly vocal one) of residents in Barnsbury (let alone of residents in Islington as a whole). Nevertheless due to the favourable 'policy environment' at central governmental level, the 'personal approaches' (described further in section 4) of the Association's members and the election of three of them to the local council, the Association succeeded in getting the traffic scheme plan adopted. Thus it would appear that institutional means (associated with mobilization of a small minority) were successful in Barnsbury.

In this section I hope to have demonstrated that 'mobilization of the social base' is only one way in which urban effects are produced. In two of Olives's cases, in most of Bonnier's, and in the three British studies described institutional approaches were also shown to be cffective. My aim is not to deny that mobilization is an important source of social change, indeed I would be, but simply to argue that both types of action are empirically important, and that the neglect of either is unjustified.

\section{(4) Organizational resources and urban effects}

In this scction we develop the point made briefly in the introduction, that studies of urban social movements within the structuralist Marxist tradition view organizations as means of linking contradictions rather than as being of importance in themselves.

According to Olives (1792) the two primary factors influencing the success of an urban social movement are the importance of the stake and the degree to which a 'social base' becomes organized into a 'social force'. The latter transformation takes place through the implantation of one or more organizations. The underlying assumption here is clearly that change is produced through the mobilization of the social base. In other words, the larger the stake, and the stronger the social force, the greater the degree of mobilization and hence the more likely an urban effect.

Thus the role of organization in the process of mobilization is important within the structuralist approach. Organizations are the means by which social forces develop and contradictions are expressed, and linked.

I wish to argue that by focussing on organizational resources we are 
able to see a feature of organizations (additional to their structural role) which affects the survival and success (i.e. urban effects) of an urban social movement. And this is true, I suggest, irrespective of whether political action is seen as occurring through mobilization, institutional means, or personal relations. The discussion will draw largely on studies of voJuntary associations, in the absence of relevant data on utban social movements.

It has been argued by Ross that 'the dependence of voluntary associations on the resources of other organizations... makes co-operation and support a vital matter.' (1972:22.) In order to achieve this support voIuntary associations have two pairs of choices, neither of which is exclusive. They may be integrated borizontally, i.e., with other social systems in the community, and/or vertically, i.e., with systems outside the community. For example, a local branch of a national political party is, by definition, vertically integrated, and may also establish links with, say, an anti-apartheid organization in its locality (hotizontal integration). Secondly, associations may be integrated with an organization, e.g., a school or workplace, or with the community at large.

The purpose of these distinctions is not merely classificatory. It may be hypothesized that associations which are integrated horizontally (and not vertically), and with the community rather than with any organization within it will encounter greater problems of survival, and be less likely to produce urban effects. Tre underlying assumption here is that integration with an organization is likely to provide access to premises, secretarial facilities, personnel, funds and even members, whereas dependence on the community at large means that these resources have to be bargained for, and this may be difficult if the association is perceived as 'unhelpful' and 'unacceptable'. Similarly vertical integtation into a national hierarchy, in so far as the latter does not take the form of a federation of semiautonomous affiliated units, but of a unified organization with local branches subject to central decision (as in some trade unions), is likely to imply a more constant flow of resources of various kinds to sustain local activity. (This depends too on the financial structure of the organization. A common feature is that local branches have to raise funds, in addition to forwarding part of membership subscriptions, for the regional and national levels of the organization. On balance local branches may contribute more than they receive in terms of services in which case vertical integration would not be more conducive to survival.)

A priori it scems reasonable to assume that the dngree of community and horizontal integration of urban social movements vould be important both to their survival and to their success. Unfortunately the data which 
would allow us to apply this type of analysis to urban social movements ${ }^{7}$ does not exist, although all manner of organizations are referred to in the empirical studies, ranging from the 'association' of friends of a businessmanintellectual (Lentin, 1973:96) to tenants' associations, trades unions, immigrant wefare associations and local political organizations (Olives, 1972: refers to the 'squatters committee' (of squatters themselves) and the difficulties encountered by a militant outside political group in obtaining support for squatters. Similarly, in his discussion of squatting, Cherki refers to the 'squatters committee' (of squatters themselves) and the 'support committee' (1973:72) (of militants and local residents). Obviously these organizations play crucial roles in the establishment, sustenance and success of urban social movements although we cannot yet say precisely how.

In addition to the resources a voluntary association derives from external sources are its considerable internal resources. The following remarks are based on muy current study of a local branch of the United Nations Association, whose aim is to promote the work of, and support for, the United Nations. Although this is not of course an urban social movement the way in which it secures resources probably holds truc for such movements.

Every member of the UNA can be seen as embedded in a social network. The term social network refers to the unbounded web of relationships of all kinds which is unanchored on any single individual. In order to use the term social network in an analytical rather than a metapborical sense, we need to considet the networks of particular individuals, i.c., 'personal networks'. (Mitchell, 1969:13.) The members of a given person's personal network will be know in a variety of institutional contexts: work, church, political party, etc. Some will be known in only one context in which case the relation is 'uniplex' or single-stranded, while others will be known in several, in which case the relation is 'multiplex'.

Every relationship in a UNA member's personal network, whether uniplex or multiplex is a potencial resource for use witbin UNA. In particular I have been able to show that committee members use relationships initiated in a wide variety of contexts (work, church, association, etc.) to secure persons as speakers and chairmen for the branch's meetings. Their ability to do this is a function of the sizc of their personal networks, which in turn partly depends on the length of the time they have been resident in the area. Since meetings are the branch's main activity it can

7. The study by Curtis and Zurcher (1973) of anti-portiography movements is suggestive of the type of data required. 
be said that the 'social capital' represented by these personal networks is crucial to the association's ability to survive and succeed in its present form. (Conversely, an organization whose members lacked externsive personal networks could be expected to encounter difficulties in obtaining resources.)

Similary, the fact that committee members each bold positions in several institutional structures (i.e. have 'cumulated positions' due to the overlapping membership of these structures) gives rise to furtber potential resources. The branch has succeeded in obtaining duplicating facilities, noticeboard space, premises, and has circulated information in many contexts through the cumulated positions of committee members. Indeed the branch's connexions with one local church, (initially limited, but now extensive due to the recruitment of church members into the UNA), are so great, and the flow of resources so large that one could almost say that the branch was (informally) integrated with the church, to use Ross's phrase.

The way in which committee members use network contacts and cumulated positions which pre-exist their membership of UNA in order to pursue the ends of the association can be seen as a sort of 'social bricolage', to adapt Lévi-Strauss's use of the term. In other words, the network contacts and cumulated positions of members can be seen as a stock of social tools, available to the association, which 'rcpresent a set of actual and possible relations' (Lévi-Strauss, 1966:18).

The underlying social process may be social excbange, i.e., 'actions that are contingent on rewarding reactions from others and that cease when these expected reactions are not forthcoming' (Blau, 1964:6). In other words, for example, the persons a member knows at work are willing to provide scrvices to him in a different context (the association) in expectation of future services which may be returned either in the work place or in some new context which only they belong to. In this way existing relationships can be 'extended'.

Alternatively, the social process may not involve social exchange but simply access to knowledge and even services which are 'free' and do not have to be repaid. The existence of 'free' services seems to be often neglected. In my current study, the local libraries and local press provide free services to the association, viz., publicity for the branch mcetings. The cxistcnce of such 'free resources' in an area obviously eases the problem of survival and facilitates success for those associations which know of their existence, and are allowed access to them. (Access was found to be restrictcd to 'acceptable' associations whose encouragement is consistent with library or newspaper policy.) 
It might be objected that reliance on personal networks and cumulated positions is a response dictated by the branch's lack of money. On the one hand, one could answer that since this is the condition of many voluntary associations so such reliance will be extensive elsewhere. But, in my view, reliance on this type of resource is not due to limited funds, but is likely to be a feature of all organizations since the occupation of positions in several structures and the possession of personal networks is quite general (though variable in degree). For this reason, I would not agree with Bonnier that the use of personal relations in political action is in any way an 'old' pattern.

In order to illustrate the importance of the resources available to voluntary associations and urban social movements through the cumulated positions and personal networks of their members we will refer briefly again to Ferris's study of Barnsbury. (Ferris, 1972.) Firstly, the Barnsbury Association included professional planners and architects who used their professional skills and knowledge in drawing up the traffic scheme. (For example, 'they formulated their objectives in such a way as to make them acceptable to the Ministry of Housing and Local Government'. (Ferris, 1972: 35), and took advantage of their knowledge of the favourable climate for traffic schemes.) The (Labour) local councillors suspected that they were using information gained in their professional capacities within local authorities and had also exploited professional contacts in the Ministry of Housing and elsewhere' (1972:64). Secondly, Barnsbury Association members were elected to the local council in 1968 as 'independents'. They used their positions as councillors, assisted by the favourable attitude of the new Conservative majority, to advance the ends of the Association. One final example of organizational resources describes by Ferris refers to the rival Barnsbury Action Group whose Secretary was «a publishing executive who was able to contribute from his business office facilities such as typing and filing. He was also able to use his knowledge of the media to get press statements published» (1972:56). Thus we see how knowlcdge and scrvices derived from cumulated positions and personal networks are important resources for urban social movements.

So far we have been discussing what Ross calls the 'association problem', namely, the problems encountered and resources used by organizations in their efforts to reach goals. To conclude, we shall refer briefly to what he calls the 'voluntarism problem', i.e., how members are recruited and kept. (The term 'voluntarism' would perhaps be better replaced by the term 'volunteer' since it is the unpaid nature of participation in voluntary associations and not any idea that participation in voluntary associa- 
tions and not any idea that participation is uncaused, that is important. See Palisi (1968), Ross (1972:27.8), Pickvance (1974).)

One of the most fruitful ways of tackling the 'voluntarism problem' would appear to be via the social exchange approach, in so far as potential members of a social movement balance the rewards of participation against the costs incurred. So far, to my knowledge, only one writer has attempted to apply the social exchange model in this field. This is the study by Weissman (1970) of a community council in an American city which seems to have been relatively successful in obtaining better 'urban' facilities for the area, at least in its earlier phase.

Weissman (1970:20-21) distinguishes four types of rewards available to individuals who participate in the council:

- emotional rewards: friendship, praise, self-esteem,

- service rewards: engcndered by services the council produces, e.g., a new school,

- ideological rewards; those that satisfy ideological commitments such as 'being a good American',

- negotiable rewards: those which have a negotiable value in structures other than the council, e.g., getting oneself in the public eye.

(A similar analysis is applied to the council's success in tecruiting different ethnic groups in the community. This fills out the notion of integration with the community, discussed earlier. The council was in fact integrated horizontally and vertically, with organizations and the community at large.)

The category 'negotiable rewards' relates to our earlier emphasis on cumulated positions. Whereas previously we showed that personal networks and cumulated positions could be used to 'import' resources into an association, by the 'extension' of social relationships, the idea of 'negotiable rewards' indicatcs how participation in an association can tesult in resources which can be 'exported' to the person's positions and relations in other structures. 'Negotiable rewards' may be difficult to assess since people are reluctant to admit to them (Weissmann, 1970:98). In the UNA branch they certainly exist: for example, the political candidate or insurance broker who make known these identities in the course of a talk.

Weissman (1970: chap. 8) argues that the absence of working-class participants in the council was due to the need for social skills, free time, money, and willingness to engage in slow formal procedures which imposed higher costs on them. Conversely the council's sports commitiee, where verbal skills and formal procedures were not necessary, was largely workingclass in composition. The absence of Italians from the council is explained 
in terms of its connexion with a Protestant settlement and clergy: only through the sports committee did the Italians participate, and this was because of the (negotiable) rewards the baseball league furnished them in their positions as churchgoers at the various Catholic churches whose teams made up the league.

This study indicates the potential of a social exchange approach to the 'voluntarism problem'. However it depends on the researchworkcr being able to establish empirically which types of reward, and what costs are associated with participation. If the exchange model is to be preserved from tautology, it is not sufficient simply to infer the existence of costs and rewards to explain participation.

In this section we have argued that organization plays a greater role in social movements than simply permitting the linking of contradictions. It is suggested that the survival and success of such movements depends on the resources they are able to obtain, free or through social exchange, from organizations in the community, from higher levcls of hierarchies, and from the personal networks and cumulated positions of their members. This is true irrespective of whether the underlying theory of political action stresses mobilization of the base, institutional meams, or personal relations, though in the latter case it is morc patent.

1. Anon. 1972. Logement et lutte de classes: compte rendu d'une ptatique militante de quartier. Espaces et Sociétés. Nos. 6-7: 59-88.

2. AsH, R. 1972. Social Movements in America. Chicago: Markham.

3. BlaLOCK, H. M. 1964. Causal Inferences in Non-Experimental Researcb. Chapel IHill: University of North Carolina Press.

4. Blau, P. M. 1964. Exchange and Power in Social Life. New York: Wiley.

5. Bonnier, F. 1972. Les pratiques des associations de quartier et les processus de «recuperation». Espaces et Sociétés. Nos. 6-7: 29-35.

6. Castells, M. 1972. La Question Urbaine. Paris: Maspcro.

7. Castells, M. 1973. Lutles Urbaines. Paris: Maspero.

8. CHERKI, E. 1973. Le mouvement d'occupation des maisons vides en France. Espaces et Sociétés. No. 9: 63-91.

9. Cun'is, R. L. and L. A. Zurcher. 1973. Stable Resources of Protest Movements: the Multi-Organizational Field. Social Forces. 52:53-61.

10. Davies, J. G. 1972. The Evangelistic Bureaucrat. London: Tavistock.

11. Dearlove, J. 1973. The Politics of Policy in Local Government. London: Cambridge University Press.

12. Dennis, N. 1972. Public Participation and Planner's Bligbt. London: Faber and Faber.

13. FERRTS, J. 1972. Parlicipation in Urban Planning: the Barnsbury Case; a Study 
of Environmental Improvement in London (Occasional Papers in Social Administration No. 48). London: Bell.

14. Lentin, F. 1973. Le quartier de Ia mouffe en rebellion (une lutte urbaine tenace dans la ville de Paris). Espaces et Sociétés. No. 9: 9-113.

15. Levi-Strauss, C. 1966. The Savage Mind (1962). London: Weidenfeld and Nicholson.

16. Mrtcineld, J. C. 1969. The Concept and Use of Social Networks, in J. C. Mitchell (ed) Social Networks in Urban Situations. Manchester: Manchester University Press.

17. Olives, J. 1972. La lutte contre la renovation urbaine dans le quartier de la "Cité d'Aliarte» (Paris). Espaces et Sociétés. Nos. 6-7: 9-27.

18. Palist, B. J. 1968. A Critical Analysis of the Voluntary Association Concept, Sociology and Social Research, 52:392-405.

19. Pickvance, C. G. 1974. Voluntary Associations as a Key Variable in F. Gittus (ed.) Key Variable, in Social Research, Vol II Politics, Voluntary Associations, and Demograpbic Variables. London: Heinemann.

20. Pingeot, F. and M. Robert. 1973. Environnement, lutte urbaine et interêts de classe. Espaces et Sociétés. No. 9:133-142.

21. Ross, J. C. 1972. Towarl a Reconstruction of Voluntary Association Theory. Britisb Journal of Sociology, 23:20-32.

22. Weber, M. 1947. The Teory of Social and Economic Organization (1922). New York: Free Press.

23. Weissman, H. H. 1970. Community Councils and Community Control: The Workings of Deniocraic Mytbology. Pittsburgh: University of Pittsburgh Press. 